\title{
ПОТЕНЦІАЛ СОЦІАЛЬНИХ ІННОВАЦІЙ У МОДЕРНІЗАЦІЇ УКРАЇНСЬКОГО СУСПІЛЬСТВА: СОЦІЛОГІЧНИЙ АСПЕКТ
}

Реалії українського сьогодення в умовах глобалізації вимагають інноваційного шляху модернізації суспільства. Проте в сучасній науковій традиції мало теоретичних обгрунтувань, які могли б забезпечити реалізацію соціальних інновацій. Адже саме соціальні інновації дають можливість забезпечити відчутне економічне зростання та інституційну здатність відповісти існуючим викликам. Вітчизняний досвід у сфері впровадження соціальних інновацій вельми обмежений в усіх сферах життєдіяльності суспільства, проте, як свідчать зарубіжні дослідження [1, 12], з переходом від індустріального суспільства до економіки знань відбувається зміна співвідношень між технологічними й соціальними інноваціями у напрямку посилення значення соціальних інновацій

Термін «соціальні інновації» в науковому дискурсі є відносно новим, але сам феномен набагато старший. $Є$ багато прикладів соціальних інновацій протягом історії людства - від дитячих садків до хосписів і від кооперативного руху до мікрофінансування $[2,9]$.

Академічні пошуки поняття соціальні інновації в науковій літературі походять від праць Макса Вебера, який визначив взаємозв'язок між соціальним порядком та інноваціями через вплив на соціальні зміни поведінки, які спочатку вважалися ненормальними. Еміль Дюркгейм у 1893 р. зазначив, що соціальне регулювання важливо враховувати для розвитку поділу праці, яка відбувається під час технологічних змін (явище соціальної згуртованості). Таке розуміння соціальних інновацій пізніше дістало своє відображення в інноваціях організації праці та суспільства [3]. На думку Й.Шумпетера, великий технічний поштовх, як снігова куля, що котиться 3 гори, супроводжується супутніми змінами, що призводить до загального та довгострокового економічного піднесення. Однак супутні йому масові інвестиції, що зумовлюють масове виробництво, є 
водночас також чинником, що сповільнює нововведення. Таке сповільнення послаблює, а потім і зводить до нуля ефект від інновацій, стимулюючи нову хвилю інновацій [4].

Соціальні інновації знову з'явилися в якості концепції та на практиці в 90-х роках XX ст. як спосіб впоратися з наслідками економічної реструктуризації, змін, привнесених IT розробками та масовим безробіттям. На сучасному етапі поняття соціальних інновацій розглядається у працях С.Голдсміта, Д.МакНіл, А.Нічолса та А.Мердока, Дж.К.Гібсон-Грехем, Дж. Мулган та багатьох інших. Поняття та концепцію соціальних інновацій як елемент сталого розвитку розглядають також вітчизняні науковці: М.З.Згуровський, А.А.Мельниченко, 3.В.Герасимчук, Г.А. Мельник, Л.В.Кривенко, І.М.Синякевич та ін. Модернізаційні процеси, які тісно пов'язані з інноваційними, досліджуються у працях П.В.Кутуєва.

Таким чином, перспективи розвитку будь-якої країни і нашої, зокрема, залежать від здатності держави мобілізувати інтелектуальний, науковий та технологічний потенціали суспільства на забезпечення збалансованого розвитку, що і є базисом для підвищення рівня життя та добробуту людей. Саме тому метою статті є подалыше теоретичне обгрунтування сутності соціальних інновацій та нових підходів до організації системи суспільних відносин, з подальшим запровадженням інноваційних шляхів модернізації суспільства.

Протягом тривалого часу в Україні суспільне споживання переважало над заощадженнями на модернізацію суспільного виробництва та розвиток людського потенціалу, що призвело до дисбалансів, які створили реальну загрозу подальшому існуванню української держави. Нехтування поточним станом справ може призвести до втрати країною інфраструктури, що забезпечує життєдіяльність суспільства, до залежності економіки та безпеки держави від зовнішніх джерел фінансування, до неспроможності відповісти всіляким загрозам і викликам.

У сучасному світі запорукою динамічного зростання є збалансований розвиток економіки, соціальної сфери та екологічного середовища на основі запровадження інновацій в усі сфери життєдіяльності суспільства, зокрема, застосування ресурсо- і природозберігаючих технологій.

Розвинутим та «розумним країнам» («smart countries») [5] властива ситуація, коли завдання держави полягає в тому, щоб створити правові та інфраструктурні можливості для мобілізації інтелектуаль- 
ного потенціалу, внутрішнього інвестиційного капіталу населення та капіталу іноземних інвесторів. Найвагоміші результати може дати запровадження сучасних механізмів міжсекторного партнерства держави, бізнесу та інститутів громадянського суспільства, самоорганізація учасників інноваційного процесу.

Виникає потреба визначення терміна «соціальні інновації». Незважаючи на актуальність даної теми та велику кількість досліджень, досі не існує універсального та загальноприйнятого його тлумачення. На нашу думку, найбільш змістовно-релевантне тлумачення терміну надали британські дослідники з Лондонської бізнесшколи Мюррей і Малган, які вважають, що «соціальні інновації це нові ідеї (продукти, послуги та моделі), які одночасно задовольняють соціальні потреби (більш ефективно, ніж альтернативи) та створюють нові соціальні відносини або співробітництво» [6].

В свою чергу, «Стенфордський вісник соціальних інновацій» містить таке визначення: «Соціальна інновація - це нестандартне рішення соціальної проблеми, яке є більш ефективним, доцільним, життєздатним (sustainable), або існуючі рішення, для яких створені цінності стосуються переважно суспільства в цілому, а не окремих індивідів» [7]. Проте у даному визначенні, на відміну від попереднього, відсутній важливий елемент соціального результату соціально-інноваційного процесу, а саме формування нових структур, відносин тощо.

Такий самий утилітарний характер має і визначення Бейкон i Файзулла: «Ми використовуємо термін «соціальні інновації», коли говоримо про нові ідеї (продукцію, послуги і моделі), розроблені для задоволення невтілених соціальних потреб. Соціальні інновації не обмежуються будь-якою однією галуззю або областю» [8].

Цікавою є думка Мамфорда, згідно з якою соціальні інновації передбачають генерацію та впровадження нових ідей про те, як люди повинні організувати міжособистісну діяльність або соціальні взаємодії, щоб вирішити одну або більше спільних цілей [9].

Важко не погодитися з канадською дослідницею Франсуа Уестлі, що «соціальні інновації $є$ ініціативою, продуктом або процесом, який глибоко змінює основні процедури, ресурси та впливи будь-якої соціальної системи» [10].

А відповідно до визначення Центру соціальних інновацій в Торонто, «соціальні інновації належать до нових ідей, які вирішують існуючі соціальні, культурні, економічні та екологічні проблеми на 
благо людей і планети. Справжня соціальна інновація завжди змінює систему, адже вона змінює сприйняття, поведінку і структури, які раніше породили ці процеси. ... I ще простіше - соціальна інновація - це ідея, яка працює на благо суспільства» [11].

Отже, соціальні інновації стосуються нових відповідей на нагальні соціальні потреби, які впливають на процес соціальних взаємодій. Вони спрямовані на поліпшення благополуччя. Вони охоплюють широкі сфери діяльності - від нових моделей догляду за дитиною до соціальних веб-мереж, від нових механізмів охорони здоров'я до нових способів заохочення людей до економії ресурсів. У свою чергу, підхід до соціальних інновацій слід розуміти не тільки як новий режим управління, що працює у різних традиційних сферах реалізації обов'язків громадян щодо ефективного вирішення проблем, пов'язаних зі зміною клімату, проблем соціальної справедливості, старіння і т.ін., але і як культура довіри та прийняття ризиків, яка необхідна для просування науково-технічних інновацій. Тобто йдеться про працю з вирішення завдань не тільки для соціуму, а й разом з цим соціумом.

Таким чином, соціальні інновації - це інновації, які є соціальними і за формою, і по суті. Зокрема, ми пропонуємо власне тлумачення соиіальних інновацій як нових ідей (продуктів, послуг та моделей), які одночасно задовольняють соціальні потреби (більш ефективно, ніж існуючі альтернативи) і створюють нові соціальні відносини та/або співробітництва. Ці інновації підвищують мобілізаційний потенціал суспільства та розширюють можливості суспільства діяти.

Втім, поряд 3 позитивними сутнісними характеристиками соціальних інновацій, які були згадані вище, є певні проблеми $з$ їх впровадженням, що підтверджує думка Н.Макіавеллі: «Ніщо не викликає таких труднощів у плануванні, сумнівів щодо успішності та небезпеки на етапі здійснення, як запровадження нових порядків... За найменшої змоги вороги атакують новатора з фанатичним запалом, тоді як інші мляво захищають його, тому і новатор і його прихильники вразливі» [12].

Наведемо приклади успішних соціальних інновацій в українському суспільстві та запропонуємо поширення вдалих практик за географічним та/або галузевим принципами.

Вартими уваги та важливими для подальшого наукового аналізу $\epsilon, ~ з$ нашого погляду, соціальні інновації, побудовані за принципом 
«3 гори вниз» - тобто ті проекти та ініціативи, які мають адміністративну підтримку, бюджетне, приватне або грантове фінансування, сформований бізнес-план та основних стейкхолдерів:

1. Ініціатива «21 листопада». Мета ініціативи - просування європейських цінностей в Україні та українських цінностей - у світі. Учасники Ініціативи «21 листопада» беруть на себе відповідальність за актуалізацію таких цінностей і поширення їх в Україні та світі. Ініціатива являє собою багатоформатний проект, що включає медійний, науковий, культурний, освітній, суспільно-політичний та інші напрямки. Ініціатива «21 листопада» є втіленням нової тенденції колективного лідерства, утвердженої Майданом. Соціальним результатом даної ініціативи можна очікувати протидію пострадянському впливу (у найширшому розумінні) в українському суспільстві.

2. Всеукраїнський конкурс «Найкращі соціальні проекти України2015», ініційований ГО «Центр соціального лідерства» 3 метою створення інформаційно-освітньої платформи найкращих соціальних проектів і практик, що реалізуються державними підприємствами, бізнес-структурами та громадськими організаціями в Україні для налагодження ефективного партнерства, навчання та підтримки організацій, які спрямовані на вирішення актуальних соціальних проблем для досягнення соціального благополуччя. Таким чином, суспільство отримує багато різнопланових соціальних проектів, спрямованих на модернізацію українського соціуму з перспективою подальшого поширення найбільш вдалих практик.

3. Ініціативний центр сприяння активності та розвитку громадського почину «СДНАННЯ» - українська неприбуткова громадська організація, заснована у 1997 р. відповідно до Конституції України та Закону України «Про об'єднання громадян». Центр створений завдяки спільним зусиллям багатьох ентузіастів громадського руху i організацій громадянського суспільства (ОГС) у справі підтримки громадської ініціативи. Головним результатом діяльності Центру $\epsilon$ об'єднання ініціативних представників суспільства та надання їм необхідних практичних інструментів для реалізації соціальних проектів та програм.

Соціальні інновації, побудовані за принципом «3 низу до гори» (тобто ініціатива представників суспільства для вирішення певної суспільної проблеми), мають вузькопрагматичний характер, вони спрямовані на вирішення конкретної соціальної проблеми. Проте, якщо така ініціатива була успішною, а проблема, яка була 
вирішена, - не унікальна, то такі соціальні інновації повинні бути поширені для вирішення типових проблем на рівні регіону/країни. Так, проект «Канцелярська сотня» (група волонтерів та небайдужих громадян, яка займається відновленням знищених документів колишніх високопосадовців), який з початку був націлений на відновлення документів, які були знищені у Межигір'ї, за належного розвитку може сприяти підвищенню прозорості суспільства та зменшенню рівня корупції у суспільстві.

Проект «Громадська варта Оболонського району» (група волонтерів та небайдужих громадян, яка займається охороною громадського порядку та співпрацює з представниками МВС у межах Оболонського району м. Києва) був майже миттєво повторений у багатьох районах Києва, а також у певних регіонах України. Як результат такої ініціативи - стрімке підвищення самоорганізації суспільства за територіальною ознакою, що неодмінно призведе до підвищення загального рівня самоорганізації суспільства.

У свою чергу, соціальні інновації в сучасній Свропі орієнтовані, насамперед, на вирішення соціальних та екологічних проблем таких як зміна клімату, безробіття, злочинність, соціальне відчуження, матеріальна бідність, міграція, нерівність у розподілі добробуту, старіння населення та ін. Причому, в сучасних умовах соціальні інновації не мають фіксованих меж, охоплюють всі сектори економіки (державний, приватний, некомерційні організації, домогосподарства) і зачіпають найрізноманітніші галузі, в т.ч. енергетику, житлове господарство, охорону здоров'я, освіту, науку, культуру та мистецтво. Спектр дії соціальних інновацій в СС досить значний - від нових моделей навчання, соціального захисту чи догляду за людьми похилого віку до нових способів зменшення кількості екологічно шкідливих речовин і відходів, переходу до низьковуглецевої економіки, розширення прав і можливостей громад тощо [13].

Отже, соціальні інновації мають більше форм практичного застосування, ніж теоретичних обгрунтувань, а спектр соціальних інновацій широкий і дуже різноманітний. Соціальні інновації охоплюють усі сфери життєдіяльності людини та суспільства від мікрофінансування до онлайн торгівлі, від нових моделей догляду за людьми похилого віку до інноваційних розробок у галузі охорони здоров'я, від спільного виробництва до краудфандингу.

Найважливіші виклики сьогодення - необхідність прискорення економічного зростання на новій якісній основі, нові вимоги до 
соціальної сфери, посилення залежності регіонального соціальноекономічного розвитку від світової економіки, курс України на євроінтеграцію - створюють для економічного зростання і нові можливості, й нові проблеми, вирішенню яких сприяють соціальні інновації.

Отже, велика кількість найбільш важливих соціальних інновацій виникли внаслідок випадкових процесів, а не детального планування політиками або науковцями. Втім, соціальні інновації можуть бути і організованим процесом. Різні програми та проекти можуть ініціювати соціальні інновації та принести вигоду на локальному та міжнародному рівнях, підвищити рівень соціальності суспільства. Ця особливість надає урядовому та/або офіціальному сектору значні важелі впливу на розвиток суспільства.

Крістіан Бейсон, директор датської агенції з соціальних інновацій (Mindlab), яка підпорядковується уряду країни, перелічив основні способи, в яких державний сектор забезпечує сталий розвиток соціальних інновацій:

- перехід від випадкових інновацій до свідомого і системного підходу до модернізації державного сектора;

- перехід від управління людськими ресурсами до побудови інноваційного потенціалу на всіх рівнях державного управління;

- перехід від вирішення завдань і проектів до організації процесів співтворчості, створюючи нові рішення з людьми, а не для них;

- перехід від адміністрування громадських організацій до постійного впровадження інновацій всередині і поза державним сектором [14].

Подальший розвиток держави потребує забезпечення поліаспектного державного управління, створення відповідних інфраструктурних інститутів, надання поштовху та підтримки соціальним ініціативам якнайшвидшого створення масштабних інноваційних проектів та програм.

Створення та стимулювання соціальних інновацій забезпечить суттєву активізацію інноваційної діяльності та забезпечення ії системного характеру, наслідком чого стануть значне та швидке зростання ВВП, зростання національного багатства, підвищення ролі та мотивації для використання «людського капіталу» в Україні та прискорить входження України до європейської спільноти демократичних держав. 


\section{ЛІТЕРАТУРА}

1. Howaldt J. Social Innovation : Concepts, research fields and international trends Електронний ресурс. - Режим доступу: http://www.intenational monitoring.com/fileadmin/Downloads/Trendstudien/Trendstudie_Howaldt englisch.pdf.

2. Повестка дня на XXI век. Конференция ООН по окружающей среде и развитию. - Рио-де-Жанейро, 1992 - Режим доступу: http://www.un.org/ $\mathrm{ru} /$ documents/decl_conv/conventions/agenda21.shtml

3. Вебер М. Избранное. Образ общества. - М., 1994.

4. Шумпетер Й.А. Електронний ресурс. Режим доступу: http://visionary.mana gement.com.ua/management/jozef-alois-shumpeter-joseph-alois-schumpeter/

5. Lynn, R., \& Vanhanen, T. National IQs: A review of their educational, cognitive, economic, political, demographic, sociological, epidemiological, geographic and climatic correlates. Електронний ресурс. Режим доступу: http://www.ttu.ee/public/m/mart-murdvee/EconPsy/2/Lynn_Vanhanen_2012_ National IQs - a review.pdf

6. Murray, Calūier-Grice and Mulgan. Open Book of Social Innovation, March 2010. - $457 \mathrm{c}$.

7. Phills Jr., Deiglmeier K., Miller D. Rediscovering Social Innovation / Stanford Social Innovation Review. - 2008.

8. Bacon, Faizullah, Mulgan \& Woodcraft. Transformers: how local areas innovate to address changing social needs. London: NESTA, 2008.

9. Mumford, M.D. Pathways to Outstanding Leadership: A Comparative Analysis of Charismatic, Ideological and Pragmatic Leadership. Mahwah. New York, 2006.

10. Westley F. Making a Difference Strategies for Scaling Social Innovation for Greater Impact Social Innovation Generation, University of Waterloo 2008. $-18 \mathrm{c}$.

11. The Centre for Social Innovation, Toronto // Електронний ресурс: $\mathrm{http} / / /$ socialinnovation.ca/innovation

12. Макіавеллі Нікколо. Флорентійські хроніки; Державець. - Харків, 2007. $-511 \mathrm{c}$.

13. Хартия «Города Европы на пути к устойчивому развитию» (Ольборгская хартия) - Ольборг, Дания, 1994. - Режим доступу: http://www.ecology. donbass.com/articles-pdf/aalborgcharter_russian.pdf

14. Bason Christian. Powering European Public Sector Innovation. Powering European Public Sector Innovation. // Режим доступу: http://www.mindlab.dk/en/cases/hvordan-styrker-man-nytaenkning-i-eus-offentlige-sektor

Маулік С.С. Потениіал соиіальних інноваџій у модернізаиії українського суспільства: соиіологічний аспект.

У статті викладається сутність соціальних інновацій та модернізації суспільних відносин, визначаються функції соціальних інновацій. Дано загальну класифікацію соціальних інновацій в сучасній Україні. Досліджується імплементація соціальних інновацій в сучасній українській економіці. 
Ключові слова: соціальні інновації, інноваційний розвиток, модернізація, соціальна відповідальність, економіка знань.

Маулик С.С. Потенциал социальных инноващий в модернизащии украинского общества: социологический аспект.

В статье излагается сущность социальных инноваций и модернизации общественных отношений, определяются функции социальных инноваций. Дана общая классификация социальных инноваций в современной Украине. Исследуется имплементация социальных инноваций в современной украинской экономике.

Ключевые слова: социальные инновации, инновационное развитие, модернизация, социальная ответственность, экономика знаний.

Sergii Maulik. The potential of social innovations in Ukrainian society modernization: sociological aspect.

The brief presents the essence of social innovations and modernization of social relations, also defines functions of social innovation. An overall classification of social innovations is made from the position of Ukraine. Using theoretical backgrounds, the implementation of social innovations in modern Ukrainian economy was studied. The peculiarity of social innovations genesis was examined and the proper conclusions regarding organizational infrastructure development and planning were presented to the public. The importance of social innovations planning was highlighted and proved with the current examples of modern Ukrainian existence. Sustainable development and social innovations as important elements of the Ukrainian shift to European mode of live were studied.

Key words: social innovations, innovative development, modernization, social responsibility, knowledge economy. 